\title{
$\mathrm{AE}$ 法による炭素繊維強化薄肉円管材の損傷メカニズムの解明 $†$
}

\author{
田中行 平* 金川 \\ 靖** \\ 村上澄 男** 川崎敦 司***
}

\section{Study on Damage Mechanism in Laminate Tube of CFRP by AE Technique}

\author{
by
Kohhei Tanaka $^{*}$, Yasushi Kanagawa ${ }^{*}$, Sumio Murakami ${ }^{* *}$
and Atsushi KaWASAKI ${ }^{* * *}$

The internal damage evolution of thin tubular specimens of CFRP was studied by means of AE (acoustic emission) measurement. The $\mathrm{AE}$ signals were detected first in the quasi static tests on the CFRP tubular specimens of $0^{\circ}, 90^{\circ}$ and $\pm 45^{\circ}$ fiber orientations, and three damage modes induced in the tests, i. e., matrix crack, delamination and fiber breakage were identified by the frequency analysis of AE signals. Then, the fatigue tests on the specimens of $\pm 45^{\circ}$ were performed under the particular stress ratios $R=0$ and $R=-0.25$ by detecting the $\mathrm{AE}$ signals for the whole process of fatigue. By use of the results of the quasi static tests, the behavior of damage development in every stage of fatigue was analyzed from the frequency analysis of $\mathrm{AE}$ signals. The $\mathrm{AE}$ signal related with matrix crack was observed in the middle of the fatigue process, and the $\mathrm{AE}$ signal due to fiber breakage was observed in the later stage of the fatigue. The $\mathrm{AE}$ signal due to delamination was mainly observed in the later period of the fatigue under stress ratio $R=-0.25$. The damage state in some stages of fatigue was also observed by a scanning acoustic microscope by interrupting the fatigue test, and the validity of the identification of damage modes by the frequency analysis was confirmed by comparing the results of AE analysis with those of the internal observation. These results agreed also with the results of other measurement of the macroscopic variation of elastic modulus, as well as with those of damage observation on the sliced section of the specimens.

Key words : CFRP, Acoustic emission, Damage process, Matrix crack, Delamination, Frequency analysis, Fatigue

\section{1 緒言}

高分子系複合材料では繰返し荷重による疲労に伴い， マトリックスき裂，層間はく離，繊維破断などの損傷が 発生する. ${ }^{1)}{ }^{2)}$ 損傷同士の相互作用や材料の個体差によっ て，異なる損傷挙動を取るものもあり，内部損傷の発生 箅所と発生時期を特定することは困難である. 複雑な損 傷挙動を理解するためには, 使用環境下で材料内部の微 視的損傷挙動を検出する手法が必要であり，そのため内 部損傷の識別法として非破壊計測法の導入が試みられて いる. CFRP に関して, Fuwa $5^{3)}$ は繰返し試験など種々 の荷重下における基本的な $\mathrm{AE}$ 挙動の研究を行い，鈴 木, 中西 ${ }^{4)}$ は, 周波数解析を用いて準静的試験での損 傷因子の同定を試みている．駒井，箕島らは，準静的引 張試験の $\mathrm{AE}$ 計測と超音波顕微鏡の観察を併用し ${ }^{5)}$ ま た，衝撃を加えた試験片に対して超音波顕微鏡によるき め細かい層間はく離の観察を行っている. ${ }^{7)}$ は繊維含有率による損傷因子の影響について検討して いる。しかしながら，疲労過程における損傷の $\mathrm{AE}$ 法に よる検討例は少ない.

複雑な損傷メカニズムを評価するためには, 内部の損 傷モード, 剛性の変化, $\mathrm{AE}$ 挙動などと複数のパラメー タが考えられるが, 内部損傷観察では対象物を切断する 必要があり, 剛性の変化を測定するには何らかの別途試
験が必要である。したがって，本研究では $\mathrm{AE}$ 計測法を 用いた，初めに，損傷モードに対応する周波数帯を特定 するため, 準静的引張試験において特徴的な損傷モード を示す種々の試験片を用いて, $\mathrm{AE}$ イベントの周波数解 析を行った. 次いで, 応力比 $R=0$ と $R=-0.25$ の 2 種類 の負荷条件下で，エッジ効果のない円管試験片の疲労試 験における $\mathrm{AE}$ 計測を行い, 準静的試験で得られた結果 から疲労損傷の進展メカニズムを明らかにした。

\section{2 実験および観察方法}

\section{$2 \cdot 1$ 試験片および試験条件}

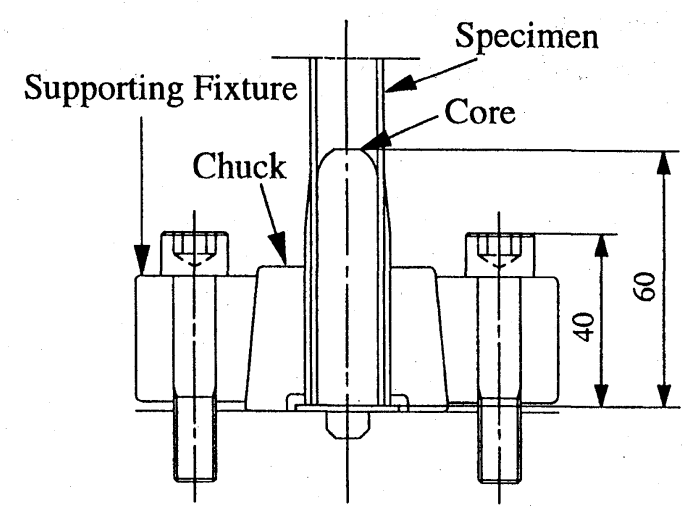

Fig. 1. Supporting condition of specimen.

$\dagger$ 原稿受理 平成 8 年 7 月16日 Received July 16, 1996

* . 名古屋大学大学院 ₹464-01 名古屋市千種区不老町, Graduate Student, Nagoya Univ., Chikusa-ku, Nagoya, 464-01

** 正 会 員 名古屋大学工学部機械工学科 广464-01 名古屋市千種区不老町, Dept. of Mech. Eng., Nagoya Univ., Chikusa-ku, Nagoya, 464-01

*** 三菱電機(侏稲沢製作所 $\quad$ T492 稲沢市菱町, Mitsubishi Electric Co., Hishi-machi, Inazawa, 492 
供試材に，プリプレグ東レ P3052（炭素繊維T300, 沨用エポキシ\#2500, 厚さ $0.125 \mathrm{~mm}$, 繊維体積含有率 59\%）で巻かれた，佳 $15 \mathrm{~mm}$ ，外径 $17 \mathrm{~mm}$, 標点間 距離 $40 \mathrm{~mm}$, 繊維配向角が $0^{\circ}, 90^{\circ}$ O1方向積層と, $\pm 45^{\circ}$ の斜向刘称積層の薄肉円管試験片を用いた。Fig. 1 に試験片の保持状態を示す。炭素繊維とプリプレグの引 張強度はそれぞれ $3528 \mathrm{MPa} １ 911 \mathrm{MPa}$ ，積層材の引張 強度は $0^{\circ}$ 単層材, $90^{\circ}$ 単層材, $\pm 45^{\circ}$ 積層材がそれぞれ $1878 \mathrm{MPa}, 52 \mathrm{MPa}, 244 \mathrm{MPa}$ である。

準静的引張試験と疲労試験の応力速度をそれぞれ $5 \mathrm{MPa} / \mathrm{sec}, 100 \mathrm{MPa} / \mathrm{sec}$ とし, 疲労試験を 2 種類の負 荷条件（応力比 $R=0$ と $R=-0.25 ） に$ 対して, 応力振幅 一定 $\left(\sigma_{a}=62.5 \mathrm{MPa}\right)$ の三角波形によって行った。

\section{2・2 AE 計測システムおよび超音波顕微鏡}

$\mathrm{AE}$ システムは, プリアンプ (MODEL5100), AE信 号処理装置（MODEL5880A），およびEPSON 社製 PC$286 \mathrm{VS}$ 改良した AE 信号解析装置（MODEL5800A） から構成され, 波形収録システムは, 波形収録装置(才 ートニクス社製， APC510）および制御コンピュータ (NEC 社製，PC-9801BA2）から棈成される。円管試験 片のテーパ部分を削った平面部分に 2 ケ所（センサ間隔 $60 \mathrm{~mm}$ ）に広帯域型センサー（NAIS B-2302N，周波数 特性 100 1600kHz) 在固定し, 総利得を $70 \mathrm{~dB}$, しき い値をノイズレベルの約5倍の $160 \mathrm{mV}$ (メインアンプ出 力電圧）で計測した. FFTによる波形データの周波数解 析 (sampling rate $0.1 \mu \mathrm{sec}$ ) では, $\mathrm{AE}$ 信号の最大パワ 一スペクトルを持つ周波数成分のヒストグラムを求めた。 超音波顕微鏡は，反射型・機械走査型のオリンパス製 $\mathrm{UH}-3$ を用い, ゲート幅 $250 \mathrm{~ns}$ で, 周波数 $30 \mathrm{MHz}$ のパル ス波モード音響レンズ（音響レンズの開口角 $50^{\circ}$ ）を使 用した。ここで, 超音波走查と同期させて山管試験片を 回転させ，円管試験片内部の円周方向展開画像を得た。

\section{2・3 内部断面観察法}

円管試験片軸に垂血方向に, 厚さ $3 \mathrm{~mm}$ 間隔で薄片 8 枚を切断し，金属顕微鏡を用いてすべての薄片のマトリ ックスき裂と層間はく離の位置・大きさ・数を測定した。 各き裂の層厚さ方向の長さ $l$ 層厚さ $l_{0}=0.125 \mathrm{~mm}$ に対 して, $N a=\left\{0<l / l_{0}<0.5\right\}, N b=\left\{0.5<l / l_{0}<1\right\}, N c=$ $\left\{l / l_{0}=1\right\}$ となる 3 つの群に分類し，マトリックスき裂密 度 $D_{\mathrm{MTC}}$ を以下のように定義する。

$D_{\mathrm{MTC}}=(N a \times 0.25+N b \times 0.75+N c \times 1) \times l_{0} / A$

ここで，A は薄片 8 枚分の総断面積である。また，層 間はく離の各長さ $l_{\mathrm{DEL}}$ に薄片の厚さ $3 \mathrm{~mm}$ を掛けたもの を層間はく離面積 $A_{\mathrm{DEL}}$ とし，全層間面積 $A_{\text {INT }}$ で，層間 はく離面積と層間はく離密度 $D_{\mathrm{DEL}}$ をそれぞれ以下のよ うに定義する。

$$
A_{\mathrm{DEL}}=l_{\mathrm{DEL}} \times 3, D_{\mathrm{DEL}}=A_{\mathrm{DEL}} / A_{\mathrm{INT}}
$$$$
3 \text { 準静的引張試験における損傷 }
$$

CFRP の痩労損傷過程を $\mathrm{AE}$ 法を用いて解明するため には，各損傷モードによって発生する $\mathrm{AE}$ 信号の同定が 必要である。ここでは, 単純な積層構成であり, しかも
その摃傷モードが明らかである一方向強化材について準 静的引張破壞試験を行い，周波数スペクトルなどの $\mathrm{AE}$ パラメータと損傷との刘心を检討する。さらに，岥労試 䮖で用いる $445^{\circ}$ 積層材についても引張試験を行い, 単 層材における $\mathrm{AE}$ 挙動との比較を行う。

Fig. 2 に, 単軸引張試験の応力 -ひずみ曲線を示す。 $\pm 45^{\circ}$ 積層材は, 破断ひず多が約 $6.5 \%$ と単層材に比べて 大きく, 著しい非弾性変形挙動が観察される。これに刘 して $, 0^{\circ}, 90^{\circ}$ 単層材は破断ひずみが小さく線形的であ る。ここで単層材の破断応力をみると，90材では $52 \mathrm{MPa}$ と小さく, $0^{\circ}$ 材では $1878 \mathrm{MPa}$ と極めて大きい。 両者の違いは損傷モードが異なるためで，公れを表す破 断部分の観察結果を Fig. 3 に示す.Fig. 3 (a) の $0^{\circ}$ 材で は, 多数の繊維が破断しているのが観察されるのに対し， Fig. 3 (b) の 90材ではマトリックス部分で試験片が破断 しており, 繊維破断はまったく生じていない。そのため, $0^{\circ}, 90^{\circ}$ 単層材を用いることによって, 繊維破断とマト

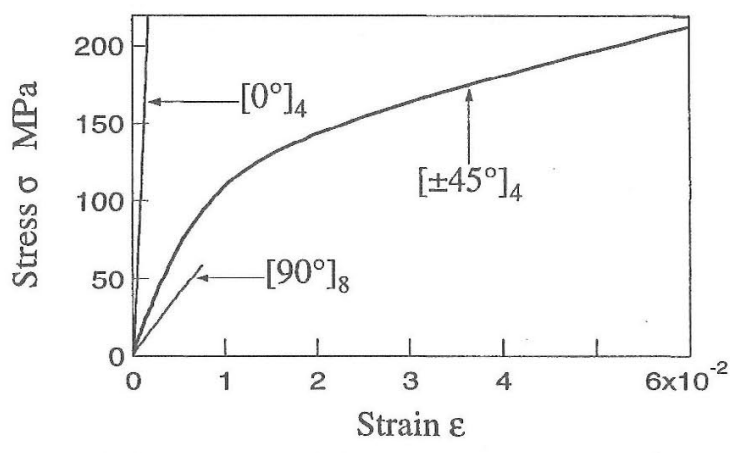

Fig. 2. Stress-strain relation under monotonic tensile loading.

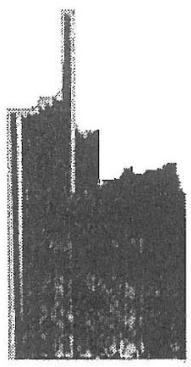

(a) $\left[0^{\circ}\right]_{4}$

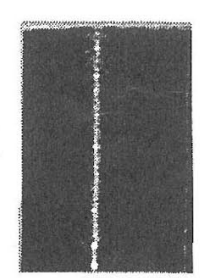

(b) $\left[90^{\circ}\right]_{8}$

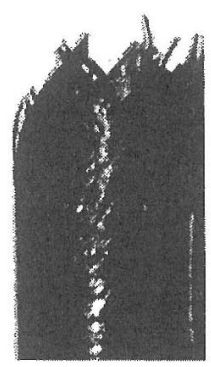

(c) $\left[ \pm 45^{\circ}\right]_{4}$
Fig. 3. Macroscopic appearance of fractured specimens.

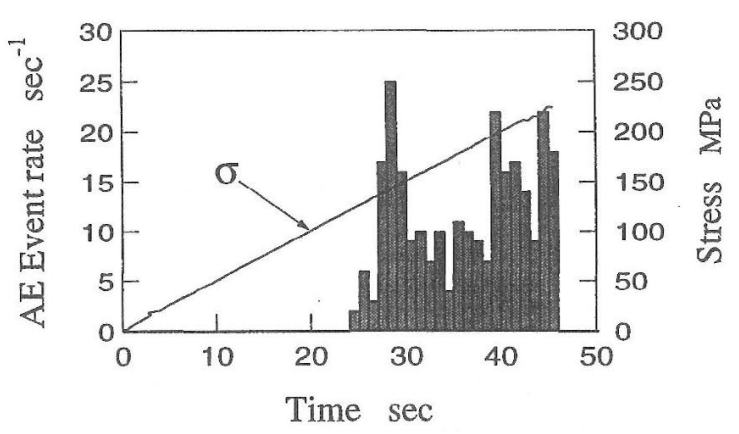

Fig. 4. Change of $\mathrm{AE}$ signals under tensile loading. 


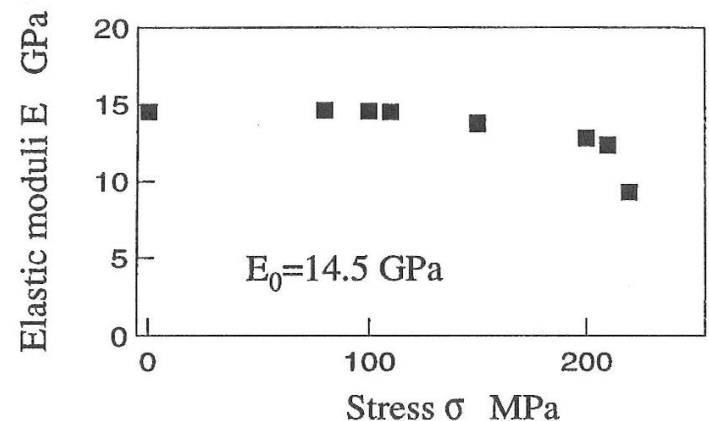

Fig. 5. Relation between elastic moduli and stress under tensile loading.
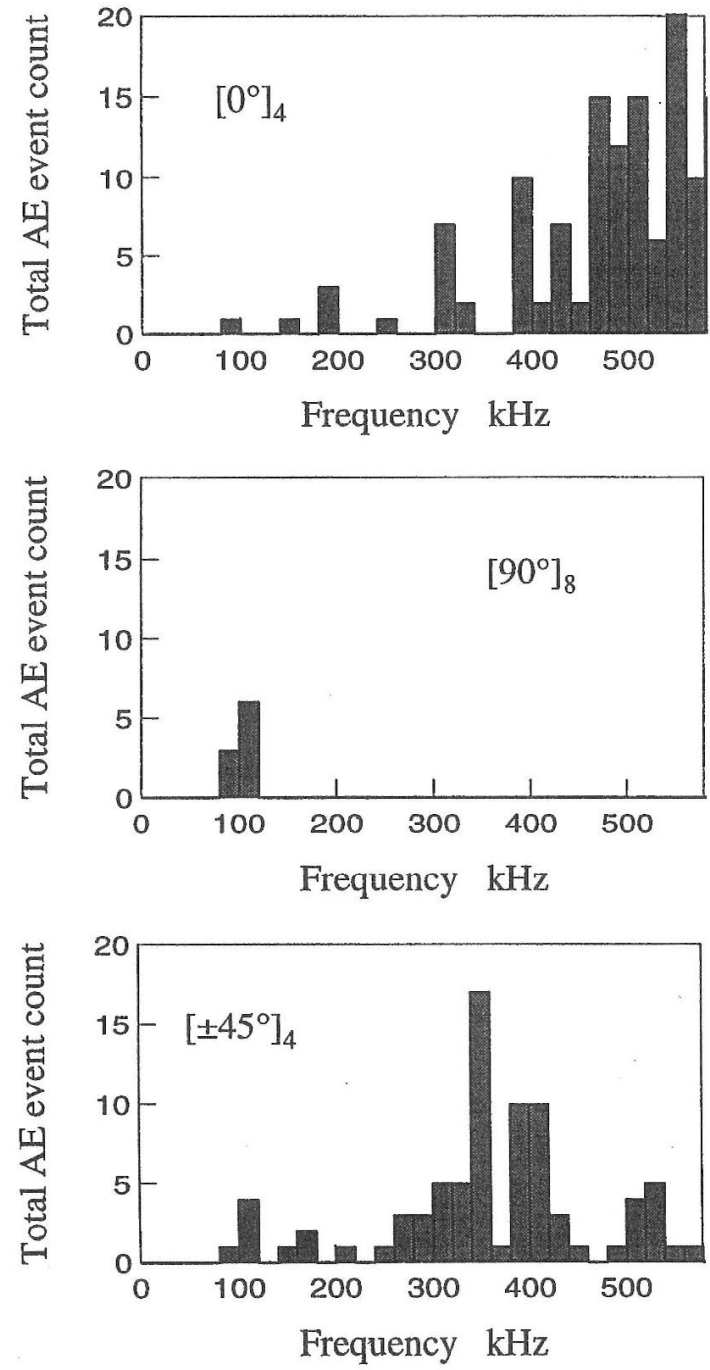

Fig. 6. Relation between AE frequency and event count under tensile loading.

リックスき裂の 2 つの損傷モードを評価することができ る. Fig. 3 (c) の $\pm 45^{\circ}$ 積層材では, 䊼維破断と，広い範 囲にわたる層間はく離が発生しており, 以下で単層材の 結果と比較して層間はく離の $\mathrm{AE}$ 周波数帯を抽出した。

損傷の力学的効果を調べるため, 準静的引張試験に㧍 ける $\pm 45^{\circ}$ 材の AE 信号と軸方向の縦弾性係数の变化を 測定し，巨視的な材料特性の変化と損傷進展とを対応付
けた。Fig. 4 は, 応力值とAE発生率の時間変化で, 応 力值が $135 \mathrm{MPa}$ を越えたところで $\mathrm{AE}$ 発生率が急激に増 大している。この $\mathrm{AE}$ 発生率が急増するときの応力を $\mathrm{AE}$ に対する初期損傷応力と定義する。また，同じ試験 片に抢ける縦弾性係数の変化を Fig. 5 に示す。非損傷材 料に抢ける初期縦弾性係数 $E_{0}$ は $14.5 \mathrm{GPa}$ で, 初期損傷 応力 $135 \mathrm{MPa}$ 以下の負荷ではほとんど変化しない。初期 損傷応力を越える応力を加えたとき, つまり $\mathrm{AE}$ が生じ てから弾性係数は減少を始め, 破断直前には $E_{0}$ の約 $66 \%$ まで急減する。このように変形過程に伴う $\mathrm{AE}$ 信号 の発生と材料の縦弾性係数の変化には密接な関連性があ り， $\mathrm{AE}$ 信号の発生を損傷の発達と考えることができる。 また, 疲労試験では弾性率が $E_{0}$ の約 $30 \%$ まで低下する ことがある. Boniface 等 8 によれば，準静的試験では積 層板に扣ける不安定なき裂の成長が試験片を破壊し, 疲 労試験では比較的安定したさ裂の成長が観察されており, このため準静的試験の弾性率の低下率が低いものと考元 られる。

次に, 準静的引張破壞試験で発生した $\mathrm{AE}$ 信号のパワ ースペクトル分布を求め, 損傷モードとの関連を検討し た。ここで，個々の AE 信号のパワースペクトルの分布 には幅があるため, $\mathrm{AE}$ パラメータとして最大のパワー スペクトルをもつ周波数成分を調べ, 各試験片のヒスト グラムを Fig. 6 に示す。 $0^{\circ}$ 単層材の分布は $500 \mathrm{kHz}$ 付近 の高周波数に偏り, $90^{\circ}$ 単層材では, 約 $100 \mathrm{kHz}$ を中心 とした成分のみが観察される。この違いは Fig. 3 で述べ た損傷モードの違いに起因しており，0材の結果から繊 維破断に伴う信号は約 $500 \mathrm{kHz}$ 付近の高周波数であり, $90^{\circ}$ 単層材の結果からマトリックスき裂によるものが $100 \mathrm{kHz}$ を中心とした低周波数に対応することが結論で きる.Fig. $60 \pm 45^{\circ}$ 樍層材の結果は広い周波数分布を示 し, 単層材の結果を考慮すると, 200 $400 \mathrm{kHz}$ 付近の 信号は $\pm 45^{\circ}$ 忉にの夕顕著にみられる周波数成分である ことから, 先に述べた層間はく離あるいは層間での摩擦 による信号であると考えられる。

\section{4 繰返し疲労試験における損傷}

ここでは，損傷に及ぼす繰返し引張負荷の影響を評価 するために，金属顕微鏡による断面観察乞超音波顕微鏡 による内部観察を行い，さらに軸方向の縦弾性係数の変 化とAE信号を測定した。試験片はすべて $\pm 45^{\circ}$ 積層材

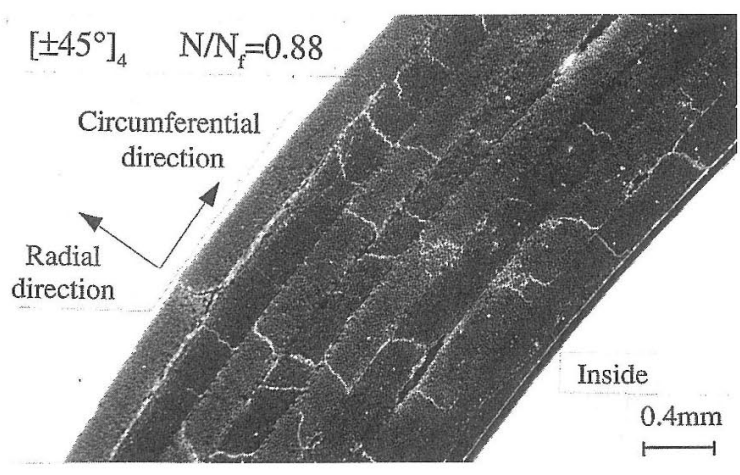

Fig. 7. Internal damage under cyclic loading. 


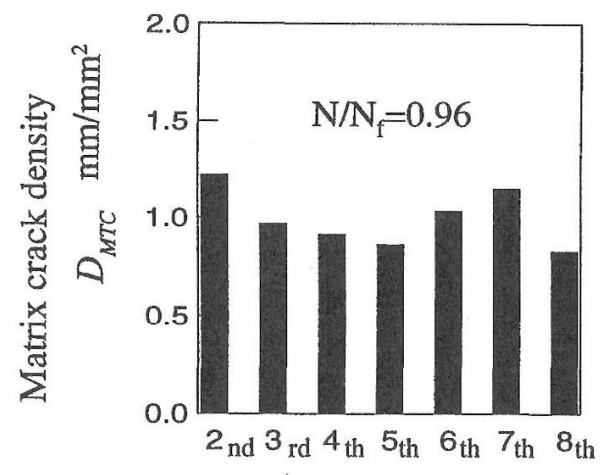

Radial Direction (from inside lamina)

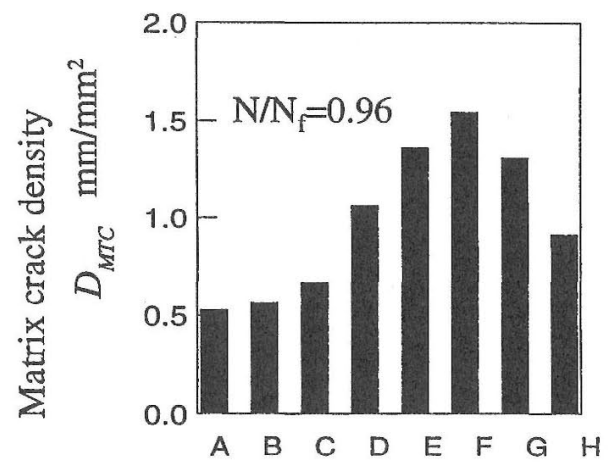

Circumferential Direction

Fig. 8. Distribution of matrix crack density $\left(N / N_{f}=0.96\right)$.

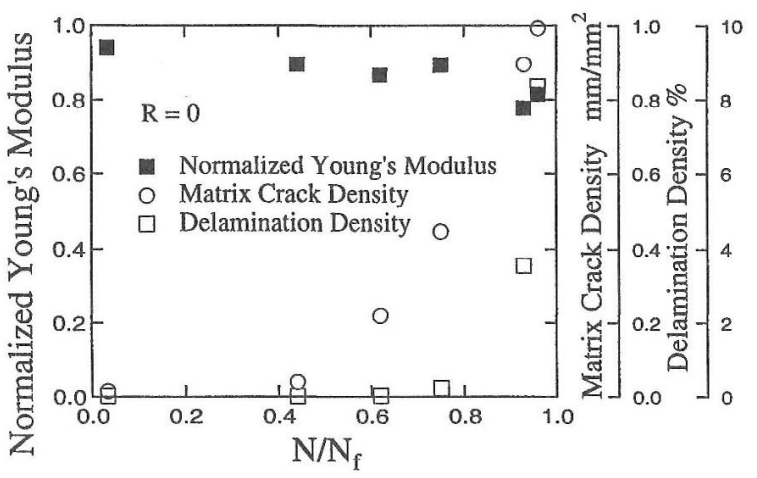

(a) stress ratio $\mathrm{R}=0$

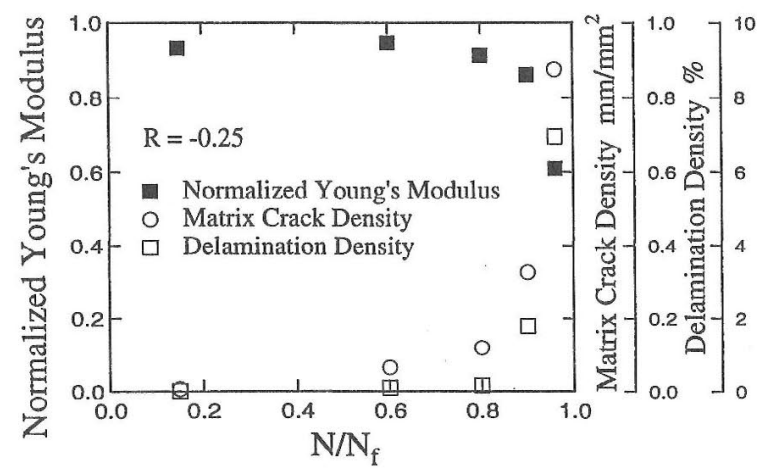

(b) stress ratio $\mathrm{R}=-0.25$

Fig. 9. Relation between elastic modulus and damage density under cyclic loading.

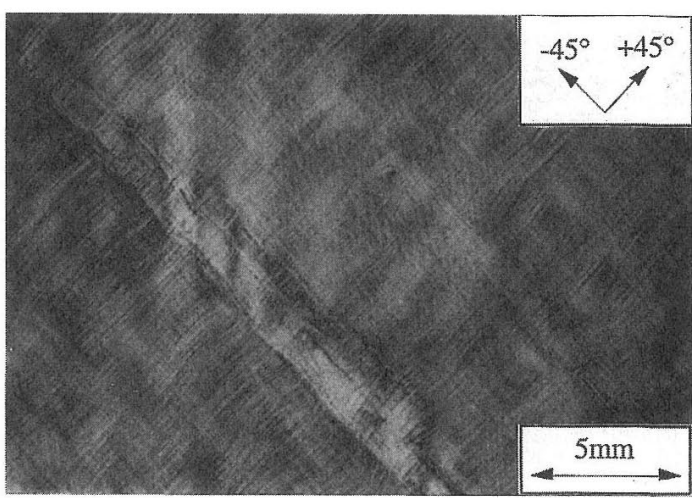

Fig. 10. Scanning acoustic microscope image $\left(\mathbb{N} / N_{f}=0.9\right)$.

で, $R=0$ と $R=-0.25$ の 2 通りの応力を負荷した

はじめに，CFRP に打ける代表的な損傷モードで西る マトリックスき裂と層間はく離に着目して疲労過程にお ける内部損傷を定量的に測定し, さらに, 縦弹性係数に 与党る損傷の影響についても検討した。Fig. 7 は金属顕 微鏡による写真の1例で，マトリックスき裂と層間のはく 離が観察される。内部損傷の観察では，損傷の発生箇所 を半径方向，円周方向，紙面に垂直な軸方向に分類して いる。

応力比 $R=0$, 寿命比 $N / N_{f}=0.96$ に打ける試験片の最 内層を除いた半径方向と円周方向のマトリックスき裂密 度の分布（軸方向 8 枚の平均値）を Fig. 8 に示す。 、卜 リックスき裂密度は半径方向には比較的均一で，この傾 向は寿命比と応力比に関倸なく認められた。また, マ卜 リックスき裂密度と層間はく離密度の山周方向と軸方向 の分布はばらつきが大きく，CFRP の損傷発生箇所が局

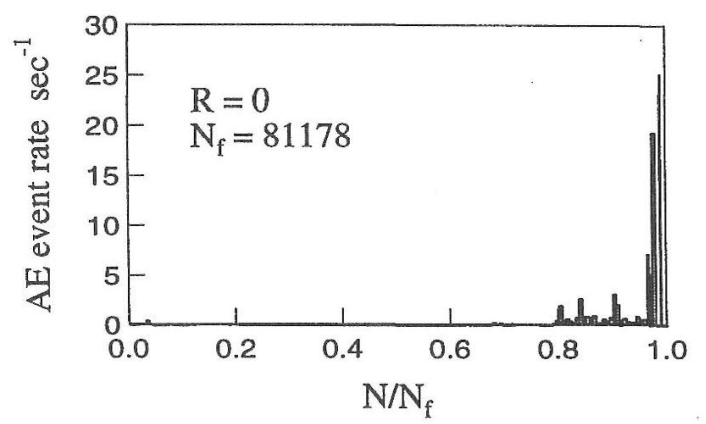

(a) stress ratio $\mathrm{R}=0$

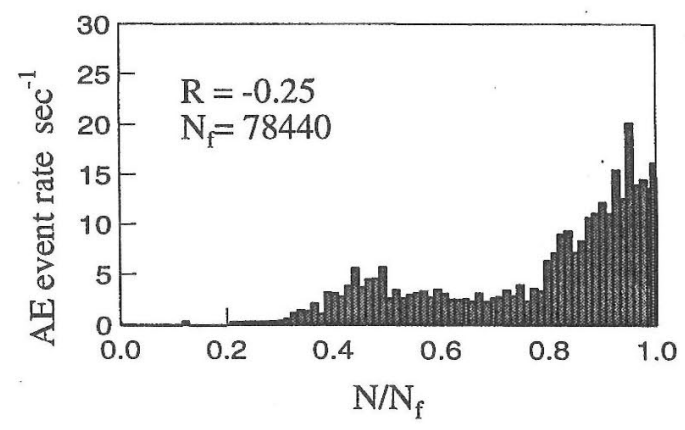

(b) stress ratio $\mathbb{R}=-0.25$

Fig. 11. Change of $\mathrm{AE}$ signals under cyclic loading. 


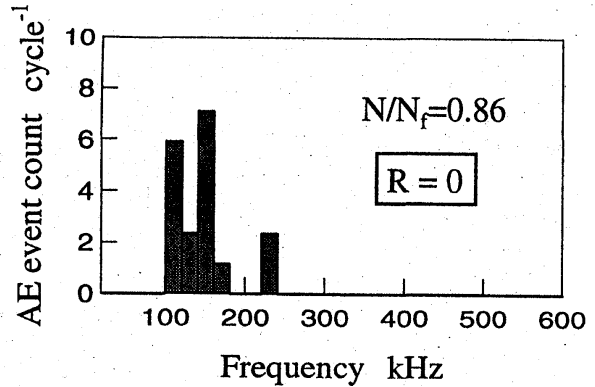

(a)

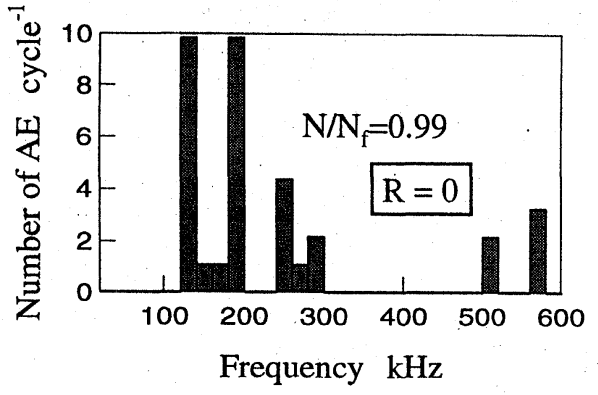

(b)

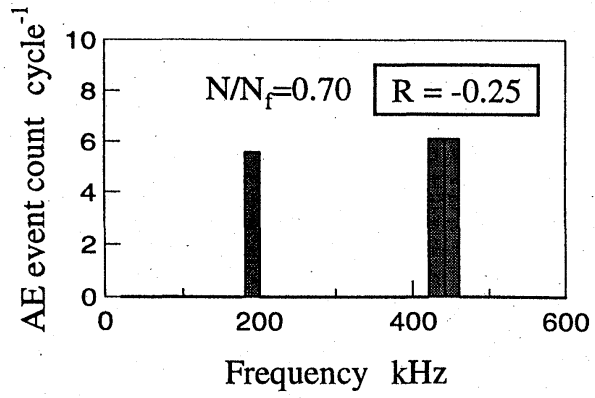

(c)

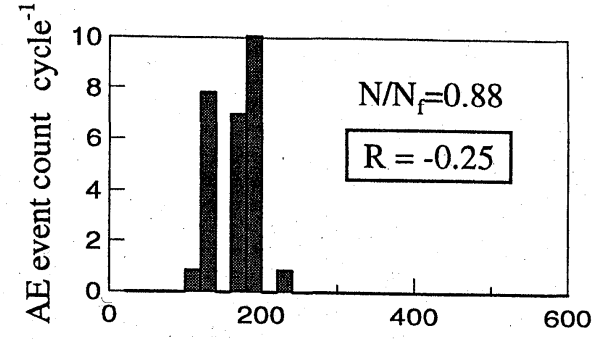

Frequency $\mathrm{kHz}$

(d)

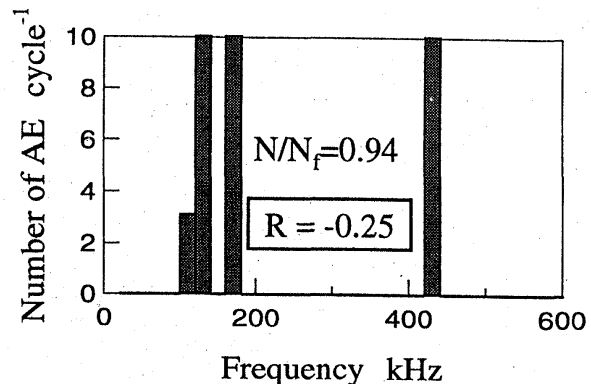

(e)

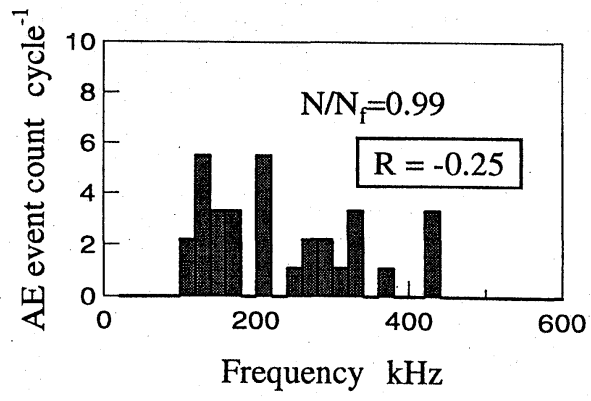

(f)

Fig. 12. Relation between $\mathrm{AE}$ frequency and event count under cyclic loading.

所的であることがわかる．本研究ではエッジ効果のない 円管試験片を用いており；曲率によって層厚さ方向に垂 直応力が作用し，円管の内側と外側で損傷状態が変わる 可能性があるが, Fig. 8 の観察結果は, 曲率の損傷への 影響が少ないことを示している。ここで，マトリックス き裂密度の高い領域と層間はく離密度の高い領域が一致 しており，それぞれの損傷が相互に影響を及ぼしあって いることを示している.

次に, 準静的引張試験と同様に, $\pm 45^{\circ}$ 材の縦弾性係数 と $\mathrm{AE}$ 信号の変化を測定し, 繰返し疲労試験における損 傷進展に伴う巨視的な材料特性の変化と $\mathrm{AE}$ 信号との関 連について検討した. Fig. 9 は, 寿命比に対するマトリ. ックスき裂密度, 層間はく離密度, 縦弾性係数の代表值 の変化である.ここで, 初期弾性率 $E_{0}$ は平均值を用い ている.まず内部損傷の変化をみると, 層間はく離密度 は応力比 $R=0$ と $R=-0.25$ の両方で, 寿命の約 8 割から 急激に増加している。これに対し，マトリックスき裂密 度は応力比 $R=0$ の場合に寿命の約 4 割から増加し, 応 力比 $R=-0.25$ の場合には寿命の約 6 割から増加してい る. 縦弾性係数は, 応力比 $R=0$ の場合に寿命の約 4 割 からゆるやかに低下し, 応力比 $R=-0.25$ の場合には寿
命の約 8 割から急激に減少している. 前節で示した縦弾 性係数の低下と損傷発生の相関関係と同様に，ここでは マトリックスき裂密度の増加とゆるやかな縦弾性係数の 低下とが対応している. ここで, 応力比 $R=0$ と $R=$ -0.25 で破断時の損傷密度が同程度であることから，層 間はく離などの損傷密度が一定量を越えると材料が破壊 すると考えられる。層間はく離と繊維破断の縦弾性係数 に対する影響に関しては, 周波数解析の結果と比較して 後で述べる.

層間はく離の変化を超音波顕微鏡により観察した結 果, 応力比 $R=-0.25$ の疲労試験において, 寿命の約 6 割まで顕著な層間はく離はみられず, $\mathrm{AE}$ 信号が増加し 始める寿命の 7 割で小さなはく離がいくつか観察され た. 寿命比 $N / N_{f}=0.9$ における中間層の超音波顕微鏡画 像を Fig. 10 に示す.内部損傷観察で層間はく離が増加 し始めた時期に対応しており,$-45^{\circ}$ 方向にのびる比較的 大きな層間はく離と繊維のゆがみが観察される，他の層 間でもすべてのはく離が繊維方向に沿って成長している. また, 応力比 $R=0$ の場合, 寿命比 $N / N_{f}=0.95$ でも大 きな層間はく離はみられず, 中・小のはく離が全体的に

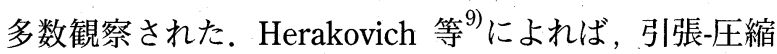


疲労試験において, 引張荷重は損傷を発生・進展させ, 圧縮荷重は損傷の進展速度を加速させる働きをします。 そのため, 圧縮荷重の作用する痏労試験では, 損傷が急 激な不安定成長を起こし， $R=-0.25$ の層間はく離の分布 がより局所的であると考えられる.

Fig. 11 は AE 発生率の寿命比に対する変化で, 応力比 $R=0$ の場合は寿命の約. 7 割から, 応力比 $R=-0.25$ の場 合には寿命の約 2 割から $\mathrm{AE}$ イベントの発生が測定され た.この $N / N_{f}=0.2 \sim 0.6$ の $\mathrm{AE}$ 信号は応力比 $R=-0.25$ 特有のもので, 低い応力レベル 0 50MPa で発生してい る.一般に繰返し荷重の場合, 平均荷重あるいは応力の 反転する付近で発生する $\mathrm{AE}$ はき裂の開閉によるものが 多い. ${ }^{10)}$ また, ここでの $\mathrm{AE}$ 信号は同一箇所で一サイクル ごとに発生しており，後で述べる周波数解析で，100〜 $200 \mathrm{kHz}$ の周波数帯となるため, 応力の反転に伴うマト リックスき裂の開閉によるものであると考えられる。こ の $R=-0.25$ の持つ $\mathrm{AE}$ エネルギーは極めて小さく, $\pm 45^{\circ}$ 材の準静的引張試験における最大 $\mathrm{AE}$ エネルギーの 約千分の一程度である. 先に定義した準静的試験の初期 損傷応力に拈ける $\mathrm{AE}$. 信号の持つエネルギーは $44 \mathrm{mV}^{2} / \mathrm{sec}$ である. $R=-0.25$ に扎いて，これに対応する エネルギーが検出されるのは寿命比 $N / N_{f}=0.8$ のとき で, これは Fig. 9 のマトリックスき裂密度の増加する時 期に相当する.このように, 初期損傷応力を $\mathrm{AE}$ 法によ って規定するためには, 負荷応力によって $\mathrm{AE}$ 計測条件 を調整する必要がある。

疲労過程における損傷モードは, $\mathrm{AE}$ 信号の挙動だけ では明らかにはできない.ここではさらに, 前節の準静 的破壊試験結果から, 周波数スペクトルによる疲労過程 の $\mathrm{AE}$ 発生源の同定を試みた. 発生した個々の $\mathrm{AE}$ の最 大パワースペクトルを持つ周波数のヒストグラムを Fig. 12 に示す. Fig. 12 (a)，(b) は，それぞれ応力比 $R=0$ お ける寿命比 $N / N_{f}=0.86,0.99$ の図で, Fig. 22 (c), (d), (e), (f) は, 応力比 $R=-0.25$ おける寿命比 $N / N_{f}=$ $0.70,0.88 ， 0.94 ， 0.99$ の結果である. Fig. 22 (a) の 100 $\sim 200 \mathrm{kHz}$ 付近の低周波数の信号は, $90^{\circ}$ 材の準静的破 壊試験の破断の瞬間に多くみられたことからマトリック スき裂に相当すると推測した。 この疲労試験でも初めに この周波数帯の信号が検出されており，マトリックスき 裂密度が最初の損傷モードであるとした Fig. 9(a) の考 察からもこの推測は妥当であろう. $500 \mathrm{kHz}$ 付近の信号 は， $0^{\circ}$ 材の引張破断過程で多く発生していたことから， 繊維破断と推測した。疲労試験でも Fig. 12(b) のように 破断の直前の $N / N_{f}=0.99$ 以後に発生しており, 試験片 の最終破壊モードが繊維破断を伴う引張破断であること と対応している。

応力比 $R=-0.25$ における寿命比 $N / N_{f}=0.2 \sim 0.6$ に発 生する信号の周波数帯はすべて $100 \sim 200 \mathrm{kHz}$ で, Fig. 12 (c) では $N / N_{f}=0.7$ と比較的早い時期から 100 $200 \mathrm{kHz}$ と同時に $420 \sim 460 \mathrm{kHz}$ の信号が検出されてい る. その後, Fig. 12(d)〜 (f) のように 100〜 200kHzの信 号は試験片の破壊まで常に発生しているのに対し，420
～460kHz の信号の発生は散発的で, 計測されないこと も多い. この周波数 $420 \sim 460 \mathrm{kHz}$ にみられる $\mathrm{AE}$ イベン 卜は䋊維破断と層間はく離の境界領域にあり，微視的な 観点からその帰属を証明することは難しい. しかし，応 力比 $R=0$ のときに比べ少ないが, $R=-0.25$ でも圧縮変 形に伴う繊維破断が発生しており，その損傷に対応する $460 \mathrm{kHz}$ 以上の信号が検出されていない点と, 初めに $420 \sim 460 \mathrm{kHz}$ 帯の信号が検出される寿命比 $N / N_{f}=0.7$ のとき, Fig. 9(b) の内部損傷観察で層間はく離が観察さ れていない点から, 周波数 $420 \sim 460 \mathrm{kHz}$ は圧縮変形に 伴う繊維破断に対応すると推測される。その場合，周波 数解析結果より $R=-0.25$ で繊維破断に対応する信号は $N / N_{f}=0.7 \sim 0.95$ まで不連続に発生し, $N / N_{f}=0.95$ 以後 に多発している. Fig. 9 (a) の縦弾性係数の変化と比較 すると, 繊維破断の多発する時期に, 層間はく離が増加 して, 剛性が急減している。一方, $N / N_{f}=0.7 \sim 0.95$ の 散発的な繊維破断は剛性に影響を与えていない，繊維破 断の発生量が少ない応力比 $R=0$ で縦弾性係数の低下量 が少ないことも考慮すると，緎維破断の多発は剛性の低 下に影響が大きいことがわかる。これに対して，層間は く離の増加は試験片の破壊する時期を決めることになる. $N / N_{f}=0.99$ の Fig. 12 (f) ではさらに $200 \sim 400 \mathrm{kHz}$ 前 半までの信号が検出された。この周波数帯は $\pm 45^{\circ}$ 材の 引張破断過程で唯一顕著にみられたもので，層間はく離 あるいは層間の摩擦によると推測した。これらの信号は, 寿命比 $N / N_{f}=0.9$ 以降から多く発生しており, 先の内部 損傷観察結果と比較して，層間に起因していると判断さ れ; 最終破壊が圧縮負荷時に生ずることと対応している. 一方, この周波数帯は応力比 $R=0$ では, Fig. 12 (b) の ように $N / N_{f}=0.9$ 以後にときおり検出されるものの，応 力比 $R=-0.25$ に比べてその数は少なく, 検出されない こともある. 破断した試験片のはく離面を観察すると， $R$ $=0$ では比較的平坦なのに対し， $R=-0.25$ では微小な凹 凸が生じていることが確認されている，応力比により， $200 \sim 400 \mathrm{kHz}$ の信号の発生挙動が異なるのは, 圧縮応 力の有無に伴う層間はく離の発達過程の違いに起因する ものと推測される.

\section{5 結言}

炭素繊維強化複合材料の損傷挙動を調べるため, 応力 比 $R=0$ と $R=-0.25$ の 2 種類の負荷条件の疲労試験で 薄肉円管試験片の $\mathrm{AE}$ 計測とその周波数解析, 縦弾性係 数の測定, 内部損傷観察の定量的な評価を行い, 以下の 知見を得た。

（1） 準静的引張負荷に伴い AE イベントが急増する ときの応力を初期損傷応力と定義すると， $\pm 45^{\circ}$ 材では， 初期損傷応力以下の負荷で縦弾性係数は変化せず, 初期 損傷応力を越える負荷に対して剛性は低下する。また， $\mathrm{AE}$ 信号の発生と剛性の低下には密接な関連があり, $\mathrm{AE}$ 信号の発生を損傷の発達と考えることができる.

(2) 準静的引張破壊試験での $\mathrm{AE}$ 信号の周波数スペ クトル解析を行った結果, 複合材料の主要な損傷モード であるマトリックスき裂, 㵶維破断, 層間はく離に対応 
する周波数成分が，それぞれ $100 \sim 200 \mathrm{kHz}$ の低周波数 成分, $500 \mathrm{kHz}$ 付近の成分, $200 \sim 400 \mathrm{kHz}$ 付近の成分に 相当すると考えられる．ここで，400〜 $450 \mathrm{kHz}$ の周波数 帯は層間はく離と繊維破断の境界領域であり，この周波 数帯に対応する損傷モードを同定することは難しい.

(3) 準静的引張試験で周波数解析により各損傷モード の同定を行い, その結果を繰返し疲労試験に適応させて, 各損傷の発生時期を評価した。ささらに, 疲労試験におけ る内部損傷観察と超音波顕微鏡観察結果とを比較して, 準静的試験における周波数解析に対する考察の妥当性を 確かめた.

（4）内部損傷観察と縦弾性係数の低下を比較した結 果，マトリックスき裂密度の増加が縦弾性係数のゆるや かな低下に, 繊維破断の多発が縦弾性係数の急減に対応 し，損傷密度が一定值を越えると材料が破壊することが わかった. また, 疲労過程で発生する $\mathrm{AE}$ 信号のエネル ギーは準静的試験と比べて小さいため, 疲労損傷の発達 を調べるときには計測条件の調整が必要である.

\section{参 考 文 献}

1) K. L. Reifsnider, K. Schulte and J. C. Duke, ASTM STP 813, 136 (1983).

2) I. M. Daniel and A. Charewicz, Engineering Fracture Mechanics, 25, 793 (1986).

3) M. Fuwa and B. Harris, J. Physics.D, 8, 1460 (1975).

4). 鈴木 恵, 中西 博, 日本機械学会論文集, 86, 1459 (1987).

$5)$ 駒井謙治郎, 箕島弘二, 日本機械学会論文集，91，54 (1992).

6) 駒井謙治郎; 箕島弘二, 日本機械学会論文集, 94, 27 (1994).

7) 木田外明, 鈴木 恵, 日本機械学会論文集, 94, 33 (1995).

8 ) L. Boniface, P. A. Smith, S. L. Ogin and M. G. Bader, Proceedings of ICCM6 and ECCM2, 3, 156 (1987).

9 ) C. T. Herakovich and Y. M. Tarnopol'skii, HANDBOOK OF COMPOSITES, 2, 254 (1989)

10）関根英樹, 鈴木 寛, 根村雅晴, 日本複合材料学会誌, 13-2, 72 (1987). 